\title{
Fundamentals of organization and trends of academic professional music education in the Ukraine
}

\section{Olena Matselyukh}

\begin{abstract}
This publication deals with the structure of modern musical schooling, as well as school as a complex of didactic, theoretical and practical aspects of learning. This came to light because of new concepts of musical education, which became the flagship of children's schooling, and the practical achievements in pedagogical endeavours of Ukrainian composer Bohdan Kotyuk: "Through studying folklore to the formation of students' national consciousness".
\end{abstract}

Key words: didactics, music education, schooling, shops and fraternities, Ukrainian music professionalism, Lviv School, concepts of music education, composer Bohdan Kotyuk. 


\title{
Základy organizace a trendy akademické profesionální hudební výchovy na Ukrajině
}

\begin{abstract}
Abstrakt
Tato stat' pojednává o struktuře moderního hudebního vzdělávání a školy jako celku didaktických, teoretických a praktických aspektů učení. To vyšlo najevo díky novým pojmům hudební výchovy, které se staly vlajkovou lodí dětského školství, a praktickým úspěchům v pedagogickém úsilí ukrajinského skladatele Bohdana Kotyuka: „Studiem folklóru k formování národního vědomí studentů“.
\end{abstract}

Klíčová slova: didaktika, hudební výchova, vzdělávání, obchody a bratrství, ukrajinská hudební profesionalita, Lvovská škola, pojetí hudební výchovy, skladatel Bohdan Kotyuk.

DOI: $10.5507 /$ epd.2019.013

\section{Introduction}

The annexing of Eastern and Western Ukrainian territories into the educational system of Soviet Ukraine took place with a rather significant time gap. Accordingly the time limits of conforming to the pressures of communist ideology, which influenced not only mentalities but also the awareness of the Ukrainian people of their national values and observance of traditions, were also very different in different regions. For certain regions, cultural and artistic values and landmarks were also quite different. This legacy of the Soviet era remains largely tangible even today - on the 28th anniversary of the sovereign and independent Ukrainian state.

\section{Multi-vector orientation of cultural and educational system in different regions of the Ukraine}

During the period of independence of the Ukraine there has been a significant activation of national music education in general and vocational training in particular. This is largely due to radical changes and new trends in the development of musical culture of the Ukraine. In particular, there is a reorientation of musical and cultural policy to revive the foundations of national consciousness, spirituality, and humanism.

It should be emphasized that the process of complete and radical rejection of the postulates of Soviet schooling requires a rather thorough reorientation not only of the 
teaching staff, but also a significant transformation of consciousness throughout society. After all, the main line of the so-called "scientific communism" ideology, which for decades was planted by the Soviet authorities, was to completely discredit perceptions of national identity both of each individual and the people in general. The distinctions between dialects or mental peculiarities between the separate regions of the Ukrainian SSR were forcibly eroded, and apart from that the differences between Slavic cultures and even entire nations within the USSR were forcibly annihilated.

\subsection{Peculiarities of centres for professional music schooling in Ukraine}

The system of music education in independent Ukrainian states has its own special structure, which is based on two trends. On the one hand, it is a centralization that manifests itself in a hierarchical structure through the Ministry of Culture and the Ministry of Education. Though these administrative structures have different tasks, they are managed from the capital Kyiv through the Cabinet of Ministers.

On the other hand, it is also a series of regional differences based on traditional ties between individual regions, both between themselves and with different influences outside Ukrainian states. For example, while the southern Black Sea region of Ukraine, through its historical past, has closer ties with the culture of the peoples of the Black Sea, the Balkans, or Asia Minor (Turkey), the Donetsk region has direct contacts with Kuban and even the Caucasus. However, the main axis of cultural, artistic and educational development of the Ukraine lies in the three major cultural centres: the modern capital of Kyiv (the centre of the Ukraine); the former capital of Soviet Ukraine, located east of Kyiv, Kharkiv; and the western capital of the Ukraine, the city of Lviv. Actually these 5 cities: Kharkiv, Kyiv, Lviv, Odessa and Donetsk are the main centres of culture and musical schooling in the Ukraine.

It should be noted that despite the state border between the two empires (Austrian and Russian), which in fact divided the Ukrainian lands for centuries, the idea of national unity and cultural integrity of the Ukraine both in artistic and educational dimensions, was always relevant. Even the creation of the national anthem is a confirmation: a Poltava-region native Pavlo Chubynsky authored the lyrics, which largely resonate with the topical spirit of the time in the Polish national anthem, or even the French Marseillaise. The melody of the main song of the Ukraine was created by the Greek-Catholic priest and professional guitarist Mykhailo Verbytskyi. Thus, in the leading song of Ukrainians, Eastern and Western Ukraine merged into a single whole. 


\subsection{The structure of modern music school: three levels of music education}

The modern music education system of the Ukraine is organized into a three-level structure. At a general education level music classes in secondary schools are compulsory in the educational system of Ukraine. The basic requirements of music lessons in a comprehensive school are a general aesthetic education of children, acquainting them with the basics of music and music literacy system.

A more profound knowledge in the field of mastering musical instruments is provided by music studios at general secondary schools. Separately, the lowest level of professional music education in the Ukraine is the 7-year music and art schools. These educational establishments function independently and are not connected with the educational system of secondary schools. That is, children who want to master a musical instrument independently choose musical instruments (to be mastered) by themselves regardless of the secondary school schedule, and choose a school and a teacher who will manage this process. This system of primary music education operates throughout the Ukraine, in the vast majority of small and large towns.

The middle link of music education in the Ukraine is an extensive system of specialized music, music-pedagogical and cultural-education colleges. This system of music training in most cities of the Ukraine is intended to prepare specialists in selected branches of music arts: pianists, violinists and other performers on string instruments, wind instruments, performers on the Spanish classical guitar, cymbals, bandura, bayanaccordion, percussionists, choirmaster and others.

A specific place in the system of secondary specialized music education is occupied by specialist music schools, which combine the training of musicians with compulsory input of secondary school knowledge. There are five such schools in the Ukraine. They are located in the cities of Kyiv, Lviv, Odessa, Kharkiv, Dnipro. The task of these schools is to find especially musically gifted children and to prepare them for a high level of performing art in various instruments while obtaining a certificate of secondary education.

Specialist secondary music education given by 5 specialized music schools, unlike music colleges, does not allow graduates to teach musical instruments at the basic music level at a music school. However, they are called upon to prepare almost a hundred thousand children for admission to a higher education institution: a Conservatory, a Musical Institute or a Music Academy. In practice, secondary level specialized music schools are the institutions that prepare young people for artistic life through participation in various concerts and contests.

The highest level of musical education in the Ukraine is the music academy, where music specialists of the highest level are trained for 5 , and sometimes 7 years (for example, vocalists), (Вітвицька, 2006). 
These institutions of higher education are:

1. Kyiv National Music Academy of Ukraine named after Petro Tchaikovskyi;

2. Lviv National Music Academy named after Mykola Lysenko;

3. Odessa National Music Academy named after A.V. Nezhdanova;

4. Kharkiv National University of Arts named after Ivan Kotliarevskyi.

5. Dnipro Academy of Music named after Mykhailo Hlinka;

6. Donetsk State Music Academy named after Sergiy Prokofiev

7. Pre-Carpathian National University Institute of Arts named after Vasyl Stefanyk.

It is also important to add to this list of Ukrainian institutions of higher music education the music departments at many Universities and Pedagogical institutes of the Ukraine. One of the most striking examples is the Faculty of Culture and Arts of Lviv National University named after Ivan Franko. This institution has a rather deep and long tradition of research in the field of musical aesthetics and philosophy. It was through its influence that Lviv Music and Aesthetic School of Roman Ingarden and Zofia Lissa appeared before the Second World War. At that time, specialists in history and music theory were taught there, all performing disciplines were studied at the Lviv Conservatory.

\subsection{School as a complex of didactic, theoretical and practical aspects of learning}

School is a phenomenon that encompasses a complex of diverse cultural and artistic and educational manifestations. Such a system of knowledge goes far beyond the educational process from elementary school to graduate school (see Дидактика вищої школи та шляхи ії розвитку на сучасному етапі). However, as a pedagogical-artistic complex, it has not yet found its detailed study in musicology, therefore - it requires a comprehensive scientific research.

The interpretation of the term "school" as a collective concept of all the functions that characterize only educational processes presupposes the neglect of those centuries-old achievements that are at the heart of schooling in Ukrainian social environment. Since the consideration of this scientific-educational methodological complex of knowledge acquisition at the all-Ukrainian level is extremely powerful and multifaceted, we will try to outline only general features of the phenomenon at the level of Lviv cultural, artistic, educational and performing tradition.

In the cultural and scientific sphere of activity of Lviv community during its almost 800 year-old history, absolutely independent types and autochthonous manifestations were formed. Recognition of the pan-European significance in the scientific and educational process came both to a broad systematic complex of knowledge characterized by the notion of "SCHOOL" (Lviv philosophical, Lviv mathematical, Lviv printing school, 
or Lviv school of architecture), and a narrow-profile artistic systems for obtaining local knowledge and local artistic achievements, which represent the culture of Lviv in the whole world. For example: the Lviv School of Decorative Arts, Lviv Choir School, as well as piano, violin and other schools. In recent decades, in addition to the abovementioned schools, new forms have been added on the basis of increased public attention to national historical heritage, Ukrainian folklore and traditions, interest in the study of music ethnography, and organology - Lviv piano, violin, cymbal, bandura, guitar, accordion-bayan and sopilka schools. Lviv opera and vocal school, represented by Alexander Myshuha, Adam Didur, Modest Mentsynskyi, Solomiya Krushelnytska and Ira Malanyuk, won world recognition. The Lviv school of symphonic and vocal-choral conducting, which was initiated by Mykola Kolessa, is well known outside the Ukraine.

\section{New concepts of musical education}

\section{Carl Orff, Petr Eben, Emil Jacques-Dalcroze, Zoltan Kodai, Shinichi Suzuki and their role in the evolutionary process of Ukrainian schooling}

The $20^{\text {th }}$ century in the world system of music didactics was marked by a departure from educational stereotypes. At that time, stylistic identity became a priority phenomenon through the work of composers. Individuality of pedagogical methods gives impressive, unexpected results. Particular attention has been paid to the personified and creative concepts of music education. They had the ability to open up new ways to master the fundamentals of music literacy and understanding of music before the initiation of the artistic organization of sound streams for younger generations of future recipients of avant-garde music works.

The combination of composers' talent for performers and their desire to be heard by the public became a powerful argument for the personal appeal of music pedagogy and the creation of our own concept of children's music education. In the 1950s, German composer, musicologist and pedagogue, Carl Orffe, who was a member of the Bavarian Academy of Arts (Carl Heinrich Maria Orff, 1895-1982), received world recognition for his music-pedagogical system which was widely disseminated. His five-volume collection, "Schulwerk" ("Music for Children") was revolutionary in elementary music pedagogy (see Orff, 1975-1983).

One of the most dedicated and consistent apologists to the concept of Carl Orff was Czech composer and teacher Peter Eben (1929-2007), who taught at Charles University in Prague and Manchester College of Music (England). In addition, he created his own system with elements of his own pedagogical findings. Peter Eben systematically conducted this course of music pedagogy by the "Schulwerk" method in Salzburg (Vondrovicová, 1993). Along with many other followers of Carl Orff all over the world in 
different continents, Peter Eben became the most successful active educator-innovator who developed and perfected the concepts of Carl Orff.

At the basis of the Orff concept of acquaintance and mastering musical laws through communication, movement and fun, lies the euryrthmics of the Swiss musical educator and composer Emile Jaques-Dalcroze, who, as early as before the First World War, organized his own "School of Music Cognition through Movement" near Dresden. Emile Jaques-Dalcroze (1865-1950) believed that the first and easiest musical instrument that a child had to master is their own body (see: Findlay). Through the natural and easy movements of his own body, a person can know the laws of musical expression (Findlay, 1999).

The use of the Dalcrozerhythmic movement also involves the Kodai Method. The Hungarian composer, folklorist, organologist, friend and associate of Bella Bartok, Zoltán Kodái (1882-1967), based his teaching methodology on a child's assessment of their opportunities and development. Progress in learning music is correlated with the gradual acquisition of new skills - from the simplest to more complex ones. But the first point of a child's comprehensive knowledge is national traditions, different styles of folklore, the customs and rituals of their motherland.

The gradual involvement of children into the world of music is through their sensory experiences, from listening, then through singing and rhythmic movement -walking, running, marching and clapping. Some exercises that accompany the singing language encourage the teacher to work out appropriate moves for accompaniment (Houlahan \& Tacka, 2015). Kodai's method as a philosophy of education was declared a non-material heritage of UNESCO in 2016.

Another world-famous music curriculum and philosophical concept of teaching music is the Suzuki Method, which was created in the middle of the $20^{\text {th }}$ century by Japanese violinist and teacher, Shinichi Suzuki (1898-1998). This method is aimed at creating a learning environment for music. All people learn from their environment. You need to create an environment in which learning music is easy and affordable, like breathing. If a 3-7 year old child is able to master the mother tongue with ease, then in a suitable environment it would be easy to master the violin, or sopilka, or any other simple musical instrument (Suzuki, 1983). By means of this musical instrument, the child will be able to communicate with other children, teachers or adults through musical language. 


\subsection{Bohdan Kotyuk: “Ukrainian Folklore in Music Lessons at School"}

\section{The concept of obtaining musical education in the process of acquiring national consciousness}

The two cornerstones of the "Concepts of the Initial Music School" by modern Ukrainian composer, organologist, musicologist and publisher, Bohdan Kotyuk are:

1. consistent orientation of the educational process towards the formation of a nationally conscious mentality of students; and this process takes place against the background of

2. practical mastering of a musical instrument - chromatic sopilka, which promotes the development of musical memory, hearing, coordination of body movements and a child's acquaintance with the world of musical art via simple music structures.

Thus, to a certain degree the Kotyuk Concept follows in the footsteps of the Kodai and Suzuki Method. There is even a peculiar parallel between the practical implementation of the Kotyuk Concept and the activities of Dmitryi Kabalevsky at school. Indeed, in the Soviet era, the role and significance of the Composers' Union (CU) of the USSR was very significant. D. Kabalevsky, a composer and board member of the USSR (CU), worked in a general education school in order to implement his concept. Bohdan Kotyuk, a member of the USSR (CU) from 1985, went along the same path (as if mirroring Kabalevsky). This unprecedented case in the history of Ukrainian schooling, when a professional composer comes to work at a secondary school in order to implement his Concept of Musical Upbringing of School Children, has no analogies.

The results of the practical implementation of his Concept by composer Bohdan Kotyuk were extremely noteworthy. This experiment lasted three and a half years. In September 1986, in a new city district of Lviv, secondary school No. 90 was opened in Sykhiv, where nearly 1500 students from all eleven classes came to receive secondary education.

Composer B. Kotyuk received quite a great pedagogical load at this school because he was enrolled as a teacher of music in all classes - from preparatory (zero) to the eighth grade. Besides this, he taught the subjects of ethics and aesthetics in final grades.

In primary school No. 90 from the very beginning, a more comprehensive study of music was introduced through the mastery of the chromatic sopilka. For all pupils and even teachers of the school, it was mandatory to attend the rehearsals of the choir; the leader, conductor and concertmaster of which was the composer Bohdan Kotyuk. At school No. 90, there was also a Music Studio, the teachers of which also participated in a general school choir, and some of the student participants were involved as soloists for performances at school in systematically organized school festivities. Thus, almost 
every month, within the framework of Lviv festive events, school No. 90 was able to demonstrate its artistic and musical achievements.

The repertoire of both the general school and teachers' choirs was dominated by the real gems of Ukrainian folklore, as well as original choir works of Ukrainian romantic and contemporary composers. A special colouring in the concert programme of schoolchildren was introduced by the performance of the sopilka ensemble, which included representatives of different age groups. Each of these concerts became an event not only for the entire district of Sykhiv, but also for the entire city of Lviv.

A culmination of concert performances of the musical achievements of School No. 90 became the final New Year's concert of 1988 at Lviv Opera and Ballet Theatre. Then, on the stage of the academic theatre in a two-hour programme with an interval, under the direction of composer Bohdan Kotyuk, more than two hundred students and teachers of School No. 90 demonstrated their achievements in musical art.

Interest in music and creativity encouraged many students of secondary school No. 90 to enter the Lviv music schools, and some even continued their studies at the Secondary Specialized Music School named after Solomia Krushelnytska. The composer Bohdan Kotyuk constantly shared his experience in implementing his Concept at teachers' seminars, conferences and at International Symposiums. This event in Lviv musical and pedagogical life remains unprecedented and worthy of further imitation nowadays (Котюк, 1989, 1990. 2009).

\section{The interaction of theory and practice in the educational process}

In contemporary Ukrainian pedagogy, there is an urgent need to outline the interaction of theory and practice in the educational process. Along with the didactic system, it is necessary to take into account a wide complex of social and artistic derivatives, which indirectly manifests itself in the existence of a locally formed system of knowledge. Amongst the most important factors, we will single out the following:

1. The concert-promoting activities of individual professional groups and according to their artistic orientations semi-professional amateur-folk groups.

2. Scientific and research foundations of Lviv intellectual environment, which naturally included in its interests the issue of the function of individual musical instruments, vocal and choral culture of Halychyna, Volyn, Podillya and Prykarpattya.

3. It is important, if not a priority, for schooling to provide material resources. Therefore, the production of musical instruments, which is put on the scientific and experimental basis, is also one of the most significant manifestations of one's identity, and therefore-one's school. 
4. The creative potential of the musical environment of Lviv is largely aimed at the formation of the original repertoire. These are not only relevant sketches or translated plays, but also authored compositions that are based on the specifics of the creation of musical fabric and are peculiarities of a particular musical instrument.

5. A vivid manifestation of the identity of the School is its self-affirmation at an international level through parity relations with other relevant structures.

6. Promoting a School's own achievements through publications and presentations by its representatives in concert halls, in artistic forums, and through publications in scientific periodicals is an important component of the establishment of this distinctive phenomenon in the cultural and musical environment.

This view of the problem and the complex approach in defining the identity of the Lviv School as a phenomenon is extremely important for the description of the productive forces in the characterization of schooling.

\section{Conclusions}

The awareness of the principles and bases of music schooling in the Ukraine is an indispensable component of increasing the professional level of teachers. Every lecturer or teacher from any part of music education is simply obliged to master the knowledge about the system of Ukrainian music education, its structure, the basic principles of music schooling in general, as well as understanding the methods of the professional work of a musician at various stages of the educational process.

These methodological recommendations are intended to highlight all the extremely important positions for music pedagogy. The structure of the music education system and the basic principles on which it operates in the Ukraine are highlighted against the backdrop of the historical development of Ukrainian states and the formation of the Ukrainian nation. This historical aspect, as well as a number of parallels between the evolution of religious and ideological basis of social development; the cultural and educational process of learning; the change in the artistic worldview and musical and pedagogical beliefs, formed the basis for revealing of the multidimensions according to their content concepts: musical education and professional schooling.

The role of Fraternity schools and guild communities became the basis of music professionalism in the Ukraine. From the origins of Ukrainian statehood and the adoption of Christianity in Kyivan Rus, an immensely important role was played by the monastic fraternity, which was a consistant and indispensable leader of the artistic and educational process. The foundations of high musical professionalism were the development and flowering of church choral polyphony. At the same time, instrumental professionalism in the Ukraine has multi-vector and multinational characteristics. It was 
created by Italian and German colonists, Ukrainian, Polish and Armenian folk musicians, as well as Gypsy and Klezmer bands.

The rise of a bright musical culture in Lviv resulted from the activities of the privileged Imperial-Royal theatre, in which a German cast worked from 1776, and which also organized in 1796 by Juzef Elsner, the "Music Academy". This relay in the concertpromoting activities of musicians in 1828 was picked up by F. X. Mozart's newly created "Society of Saint Cecilia", and subsequently, in 1853, Conservatory at the Halychyna Music Society was established.

Special attention in the methodological study of music education systems and professional music schools, was focused on the interpretation of the term school as a collective concept of all functions, which not only characterizes the actual educational process, but also covers the whole complex scientific and educational acquisition of knowledge. The only way for each teacher to comprehend the system of music education in the Ukraine is to characterize those features that include both the specifics of didactic methods of mastering professional knowledge, as well as the material and technical base and the individualized methods of organization in the educational process. This focus upon different aspects in this article enables the reader to comprehend the structure and principles of building a system of children's music education in the Ukraine.

Awareness of the problems of development and evolutionary processes, and of the multi-dimensional and significant tasks facing the Ukrainian musical and didactic system, by each Ukrainian teacher at every level of music education, is the only true way to reach the summit of High Music Art. These summits are reached not only because of talent, but above all because of the professional training of a musician under the guidance of a scientifically and methodologically thoughtful and devoted teacher-tutor.

\section{References}

Дидактика вищої школи та шляхи її розвитку на сучасному етапі. Retrieved from http://studentlib.com/referat-55045-didaktika_vischoi_shkoli_ta_shlyahi_ii_rozvitku_na_suchasnomu_etapi.html

Findlay, E. (1999). Rhythm and Movement: applications of Dalcroze Eurhythmics. Van Nuys: Alfred Music.

Houlahan, M. \& Tacka, Ph. (2015). Kodály Today: A Cognitive Approach to Elementary Music Education. New York: Oxford University Press.

Котюк Б. (1990). Виховання національної свідомості в учнів на основі народної пісні // Матеріали обласної науково-практичної конференції “Народна пісня в музичному вихованні школярів". Львів: Укр. фонд культури.

Котюк Б. (2009). Книга для вчителя музики. [У співавторстві з Дверієм Р.Є.] Львів: Світ.

Котюк Б. (1989). Концепція музичного виховання на уроках музики у загальноосвітній школі. // Матеріали III Всесоюзного фестивалю народної творчості. Львів: Упр. нар. освіти.

Orff, C. (1975-1983). Carl Orff und sein Werk. Dokumentation. 8 Bde. Tutzing: H. Schneider. 
Suzuki, S. (1983). Nurtured by Love: The Classic Approach to Talent Education. Van Nuys: Alfred Publishing.

Вітвицька С. С. (2006). Основи педагогіки вищої школи: Підручник за модульно-рейтинговою системою навчання для студентів магістратури. - Київ: Центр навчальної літератури Vondrovicová, K. (1993). Petr Eben. Praha: Schott Music Panton.

Olena Matselyukh is the leading Ukrainian organist. She is a soloist of the Lviv Organ and Chamber Music Hall, as well as a soloist of the Lviv and Rivne Philharmonics. She holds her concert tours throughout Ukraine - from Donetsk, Dnipro, Odessa and Berdyansk to Chernivtsi, Vinnytsia, Lutsk, Ivano-Frankivsk, Letychiv, Khmelnytsky, Berehove, Stryi, Sambir and Mostyska, close to the Polish border. As an organist she constantly tours in Switzerland, Germany, France, Spain, Poland, the Czech Republic and Denmark.

In 2017 and 2018 Olena Matselyukh, one of the best interpreters of Johann Sebastian Bach, opened the Bach Festival in Brno (the Czech Republic) and in Wrocław (Poland). In Poland, due to her talent, Olena Matselyukh is given a warm welcome by her fans at several other festivals - in particular, in "Music in Old Kraków".

Approbated in numerous concerts, the long-term and diverse creative work of organist Olena Matseliukh is recorded on her CDs "Benedictus" and "Amazing Grace", on composer Bohdan Kotyuk's CDs "Reflections" \& "Mood and Spirits" and on the joint CD "Syrinx" with the performer on the Pan Flute, Ihor Matselyukh.

Olena Matselyukh is also known as a scientist. Her research in the domain of organ art is regularly published in Ukrainian and foreign almanacs, musicology scholarly collections and journals. As a doctoral student of the second oldest university in the Czech Republic, the Palacký University in Olomouc, Olena Matselyuk is to present her doctoral dissertation on "The Sacred and profane in the organ creativity of the composers of Ukraine and the Czech Republic".

Olena Matselyukh is the Artistic Director of the VI. and VII. International Festivals of Organ Music "Diapazon", which took place to a freat public acclaim in the Lviv Organ and Chamber Music Hall in October 2016 and July 2017. In the Lviv Philharmonic, she is the founder and director of the International Summer Festival "Pizzicato e cantabile" and International Festival "Music in Old Lviv". She is the producer and co-organizer of the International Festivals of Organ Music in Rivne and Chernivtsi - "Musica viva Organum 2018". 